\title{
Factors associated with body image dissatisfaction of the elderly who practice weight training
}

\author{
Fatores associados à insatisfação com a imagem corporal \\ em idosos praticantes treinamento de força
}

\author{
Daniel Vicentini de Oliveira ${ }^{[a, b]}$, José Roberto Andrade do Nascimento Júnior ${ }^{[c]}$, \\ Caio Rosas Moreira ${ }^{[\mathrm{d}]}$ Sônia Maria Marques Gomes Bertolini ${ }^{[\mathrm{e}]}$, Alessandra Regina Carnelozzi Prati ${ }^{[\mathrm{b}]}$, \\ Cláudia Regina Cavaglieri ${ }^{\left[\mathrm{a}^{*}\right.}$
}

[a] Universidade Estadual de Campinas (UNICAMP), Campinas, SP, Brazil

[b] Faculdade Metropolitana de Maringá (UNIFAMMA), Maringá, PR, Brazil

[c] Universidade Federal do Vale do São Frascisco (UNIVASF), Petrolina, PE, Brazil

[d] Universidade Estadual de Maringá (UNICAMP), Maringá, PR, Brazil

[e] Centro Universitário de Maringá (UNICESUMAR), Maringá, PR, Brazil

\begin{abstract}
Introduction: The body image is a multidimensional construct of the internal and external representations of the corporal structures added to the physical appearance, which can be influenced by aging. The weight training can be an important exercise to help elderly to face all the changes arising from aging, being one of them the dissatisfaction with body image. Objective: This study aims at identifying the factors associated with body image dissatisfaction of the elderly who practice weight training. Methods: This is an observational cross-sectional study. The sample, chosen by convenience and intentionally, embraced 174 male and female elderly subjects who practice weight training at one of the 15 fitness centers drawn for the research that offered this modality of physical exercise in Maringá city, state of Paraná, Brazil. A questionnaire with sociodemographic and health
\end{abstract}

\footnotetext{
DVO: Doctoral student, e-mail: d.vicentini@hotmail.com JRANJ: PhD, e-mail: jroberto.jrs01@gmail.com CRM: Doctoral student, e-mail: crosasmoreira@gmail.com SMMGB: PhD, e-mail: sonia.bertolini@unicesumar.edu.br ARCP: MS, e-mail: lecarnelozzi@hotmail.com CRC: PhD, e-mail: cavaglieri@fef.unicamp.br
} 
profile questions was used, as well as the BSQ to assess body dissatisfaction. Data analysis was carried out by using a descriptive inferential statistical approach with the Chi-squared test, Fischer's exact test, and binary logistic regression, adopting a significance when $\mathrm{p}<0.05$. Results: The majority of the elderly showed no body dissatisfaction (82.2\%). There was a significant association among the absence of body dissatisfaction and the following items: retirement $(p=0.031)$, current study $(p=0.035)$, self perception of health $(p=0.016)$, body self perception $(p=0.001)$, and practice time $(p=0.027)$. Conclusion: Based on the results obtained, it can be concluded that the sociodemographic factors are intervenient when considering body dissatisfaction of the elderly people who practice weight training.

Keywords: Body Image. Aging. Resistance Training. Health Promotion.

\section{Resumo}

Introdução: A imagem corporal é um construto multidimensional das representações internas $e$ externas das estruturas corporais adicionadas à aparência física, que podem ser influenciadas pelo envelhecimento. $O$ treinamento com pesos pode ser um importante exercício para ajudar os idosos a enfrentar todas as mudanças decorrentes do envelhecimento, sendo um delas a insatisfação com a imagem corporal. Objetivo: $O$ objetivo do estudo foi identificar os fatores associados à insatisfação com a imagem corporal de idosos praticantes de musculação. Métodos: Trata-se de uma pesquisa observacional, de delineamento transversal. A amostra, escolhida por conveniência e de forma intencional, foi composta por 174 idosos, de ambos os sexos, praticantes de musculação em uma das 15 academias sorteadas para a pesquisa, que ofereciam esta modalidade de exercício físico no municípío de Maringá, Paraná, Brasil. Foi utilizado questionário com questões de perfil sociodemográfico e de saúde, e o BSQ para avaliação da insatisfação corporal. A análise dos dados foi realizada mediante uma abordagem de estatística descritiva e inferencial, por meio dos testes Qui-quadrado, exato de Fischer, regressão logística binária, adotando significância quando $p<0,05$. Resultados: Observou-se ausência de insatisfação corporal na maioria dos idosos (82,2\%). Foi encontrada associação significativa de ausência de insatisfação corporal com a aposentadoria $(p=0,031)$, estudar atualmente $(p=0,035)$, com a auto percepção de saúde $(p=0,016)$, auto percepção corporal $(p=0,001)$ e tempo de prática $(p=0,027)$. Conclusão: Por meio dos resultados obtidos, pode-se concluir que os fatores sociodemográficos podem ser considerados intervenientes na insatisfação corporal em idosos praticantes de musculação.

Palavras-chave: Imagem Corporal. Envelhecimento. Treinamento de Resistência. Promoção da Saúde.

\section{Introduction}

The body image is the multidimensional construction of the internal and external representations of the corporal structures added to the physical appearance, and may be influenced by sex, age, means of communication, in addition to beliefs and values inserted in a culture [1]. Such values can change throughout life due to the fact that it is a subjective mechanism in which the mental representation of physical appearance depends on the way the individual conceptualizes his/ her own body [2].
Therefore, the search for the ideal body shape based on unattainable models or references, which are far from the reality of most of the population, has as consequence the increasing dissatisfaction of people with their own appearance [3, 4]. Considering this theme there is a vast amount of research based on the search for an ideal body image that assess the levels of satisfaction or dissatisfaction of some individuals with their body [5], and comparisons between the self esteem and body image satisfaction of people who practice physical activities [6]. 
In this sense, this topic also can be evaluation in elderly body image, showing that practice physical exercise, which shows that the practice of physical activities favors the experience with the body by promoting a positive and integrative body image [7]. Beyond to a better perception of body image, the practice of physical exercise in the elderly seems to be a factor that allows greater satisfaction with life and self-esteem during aging $[6,8]$.

According to Matos [9], such an appreciation of body image has increasingly taken the elderly to fitness centers, as well as to gyms for senior citizens, aesthetic centers, nutritional or pharmaceutical support and even to plastic surgeries in order to improve body dimensions. In this sense, most studies show fragmented analyzes on the level of physical activity, satisfaction or dissatisfaction of body image and other factors related to the theme, but less is discussed about the influence of weight training in elderly body image.

Therefore, this study aims at identifying the factors associated with the dissatisfaction with the body image of the elderly who practice weight training.

\section{Method}

This is a quantitative observational cross-sectional study.

Sample

The sample, chosen by convenience and intentionally, embraced 174 male and female elderly subjects (65.06 \pm 4.98 years) who practiced weight training at one of the fitness centers in Maringá city, state of Paraná. These centers (15) were chosen for data collecting for offering such a modality, and they were randomly drawn according to the list of those accredited in the Regional Council of Physical Education of Paraná.

The elderly were properly enrolled in the weight training modality in one of such fitness centers. The individuals with neurological and cognitive deficits, which were perceptible to the researchers and that prevented the elderly from answering the questionnaires, were excluded.
Those who agreed to participate in the research signed the Free Informed Consent Form (FICF). They were interviewed in the fitness centers, after their authorization.

The study was approved by the Standing Committee on Ethical Research with Humans under the opinion $\mathrm{n}^{\circ} 1.694 .517 / 2016$.

Tools

A semi-structured questionnaire was used to characterize the sociodemographic, health, and weight training profiles of the sample, which consisted of questions related to the age group (60 - 70 years old, 71 - 80 years old); sex (female, male); marital status (with a partner, without a partner); monthly income in minimum wage (MW) related to the amount in force in 2016 (up to $1 \mathrm{MW}$; 1.1 to $2 \mathrm{MW}$; over $2 \mathrm{MW}$ ); education (illiteracy, incomplete elementary education, complete elementary education, complete high school, complete higher education); smoking (has never smoked, has already smoked, currently smokes); race (Caucasian, black, Asian); being retired (yes, no); occupational situation (active, non-active); being a current student (yes, no); health selfperception (bad, regular, good, very good, excellent), body self-perception (slim; normal; fat); weight training time (less than 6 months, 6 months to 2 years, more than 2 years); weekly frequency of weight training $(2,3,4,5$ or more times); reason for weight training practice (medical recommendation, leisure, aesthetic); body image dissatisfaction; being practicing another exercise (yes, no).

Body dissatisfaction was assessed by using the BSQ questionnaire, which consists of 34 questions and is self-filling - a 6-point Likert scale (1: never to 6: always). After summing the points of the questions, the classification of body dissatisfaction levels was carried out: absence of body dissatisfaction - under 80 points; a slight dissatisfaction - from 80 to 110 points; a moderate dissatisfaction - from 110 to 140 points; a severe body dissatisfaction - score equal to or above 140 points. The evaluation was performed by considering the corporal form and concern expressed during the last four weeks of the date of collection [10]. 
Procedures

Initially, the Regional Council of Physical Education (CREF/PR) was contacted in order to obtain the list of fitness centers that offered weight training, located in Maringá city, state of Paraná. Subsequently, 15 fitness centers were drawn. After the authorization of those responsible for the centers, data collection was started, before or after the practice of weight training. The elderly who accepted to participate in the research signed the Free Informed Consent Form. Data collection was carried out from May to July, 2016.

\section{Statistical analysis}

Data analysis was carried out by using the SPSS 22.0 Software, in addition to a descriptive and inferential statistics approach. In the descriptive approach, the absolute and relative frequencies were distributed to the categorical variables (sociodemographic, health and physical activity). The numerical variables were expressed through the mean and standard deviation. In inferential statistics, the Chi-squared test and, when necessary, Fisher's exact test, were used to investigate the proportional differences considering the prevalence of body dissatisfaction based on sociodemographic, health, and physical activity variables. The Binary Logistic Regression (gross and adjusted analysis) was used to evaluate the associations of sociodemographic, health and physical activity variables (independent variables) with the presence of body dissatisfaction (dependent variable) of the elderly. For both Chi-squared and Logistic Regression, the BSQ was reorganized into two categories: absence of dissatisfaction - those classified as free from body dissatisfaction; and presence of dissatisfaction those who were classified as having some level of body dissatisfaction (slight, moderate or severe). For modeling the regression analysis only those variables that showed a level of significance equal to or less than 0.20 , considering the association with the presence of body dissatisfaction in the chi-squared test, were considered. The model fit was verified through the Hosmer-Lemeshow test. The analyzes were performed by using the SPSS software version $20.0(\mathrm{p}<0.05)$.

\section{Results}

Out of the 174 elderly subjects evaluated, 104 were female (59.8\%) and 70 were male (40.2\%). The majority were 60-70 years old (83.9\%); they had finished high school (58\%), had a partner (55.7\%), had an income above 2 minimum wages (55.1\%); they were Caucasian (78.7\%), and they were not retired $(73.6 \%)$, but with an inactive occupational situation $(61.5 \%)$.

Table 1 -Sociodemographic profile of the elderly who practice weight training in Maringá - PR

\begin{tabular}{lcc}
\hline VARIABLES & $\boldsymbol{f}$ & $\%$ \\
\hline Sex & 70 & 40.2 \\
Male & 104 & 59.8 \\
Female & & \\
Marital status & 97 & 55.7 \\
With partner & 77 & 44.3 \\
Without partner & & \\
Age group & 146 & 83.9 \\
60 a 70 years & 28 & 16.1 \\
More than 70 years & & \\
Monthly income & 21 & 12.1 \\
Up to 1 MA & 57 & 32.8 \\
1,1 a 2 MA & 96 & 55.1 \\
More than 2 MA & & \\
Education & 12 & 6.9 \\
Illiterate & 30 & 17.2 \\
Fundamental Incomplete & 31 & 17.8 \\
Complete fundamental & 101 & 58.0 \\
Average full & & \\
Breed & 137 & 78.7 \\
Caucasian & 31 & 17.8 \\
Black & 6 & 3.4 \\
Asian & & \\
Retirement & & \\
Yes & 46 & 26.4 \\
No & 128 & 73.6 \\
Occupational situation & & \\
Active & 107 & 61.5 \\
\hline Inactive & & \\
\hline & & \\
\hline
\end{tabular}

Considering health and practice of weight training profiles of the elderly (Table 2) it was verified that the majority had a good health perception (43.1\%); a 
normal body self-perception (70.7\%); weight training time from 6 months to 2 years (34.5\%) and above 2 years (34.5\%); and a frequency of weight training from 3 to 4 times a week (63.8\%). The majority of the elderly reported having started weight training due to medical recommendation (71.3\%). The majority of the elderly (82.2\%) showed no body dissatisfaction.

Table 2 - Health and physical activity profiles of the elderly who practice weight training in Maringá - PR

\begin{tabular}{lcc}
\hline VARIABLES & $\boldsymbol{f}$ & $\%$ \\
\hline Health self-perception & 38 & 21.8 \\
Bad/Regular & 75 & 43.1 \\
Good & 65 & 35.1 \\
Very good/Excellent & & \\
Body self-perception & 11 & 6.3 \\
Slim & 123 & 70.7 \\
Normal & 40 & 23.0 \\
Fat & & \\
Weight training time & 54 & 31.0 \\
Less than 6 months & 60 & 34.5 \\
6 months to 2 years & 60 & 34.5 \\
More than 2 years & & \\
Weekly frequency & 30 & 17.2 \\
1 to 2 times & 111 & 63.8 \\
3 to 4 times & 33 & 19.0 \\
5 times or more & & \\
Reason for practicing & 124 & 71.3 \\
Medical recommendation & 41 & 23.6 \\
Leisure & 9 & 5.1 \\
Aesthetics & & \\
Body image dissatisfaction & 143 & 82.2 \\
Absence & 31 & 17.8 \\
Presence & & \\
Being practicing another exercise & 72 & 41.4 \\
Yes & 102 & 58.6 \\
\hline No & & \\
\hline & & \\
& & \\
\hline
\end{tabular}

When analyzing the association among the body image dissatisfaction and the socio-demographic variables (Table 3), a significant association with retirement was found ( $p=0.031$ ), as well as with the fact of being a current student ( $p=0.035$ ). It should be highlighted that there is a higher proportion of individuals with no body dissatisfaction who are not retired (85.9\%) and who have not currently been studying (83.7\%).
Table 3 - Association of body image dissatisfaction with the sociodemografic variables of the elderly who practice weight training in Maringá - PR

\begin{tabular}{|c|c|c|c|c|}
\hline \multirow{3}{*}{ VARIABLES } & \multicolumn{2}{|c|}{$\begin{array}{l}\text { Body image } \\
\text { dissatisfaction }\end{array}$} & \multirow{3}{*}{$x^{2}$} & \multirow{3}{*}{$\mathbf{P}$} \\
\hline & $\begin{array}{c}\text { Absence } \\
(n=143)\end{array}$ & $\begin{array}{c}\text { Presence } \\
(n=31)\end{array}$ & & \\
\hline & $f(\%)$ & $f(\%)$ & & \\
\hline
\end{tabular}

Sex

Male

Female

$62(88.6) \quad 8(11.4)$

$81(77.9) \quad 23(22.1) \quad 3.263 \quad 0.071$

Age group

Up to 70 years old

More than 70 years old

$121(82.9) \quad 25(17.1)$

22 (78.6) $6(21.4)$

$0.297 \quad 0.593$

Marital status

With a partner

Without a partner

$83(85.6) \quad 14(14.4)$

$60(77.9) \quad 17(22.1)$

1.7130 .191

Monthly income

Up to 1 minimum wage

$19(90.5) \quad 2(9.5)$

1 to 2 minimum wages

More than 2 minimum

wages

$44(77.2) \quad 13(22.8)$

$0.033 \quad 0.857$

$80(83.3) \quad 16(16.7)$

Education

Illiteracy

$10(83.3) \quad 2(16.7)$

Incomplete Elementary

Education

Complete Elementary

Education

$27(90.0) \quad 3(10.0)$

$0.537 \quad 0.464$

Complete High School

Smoking

Has never smoked

$90(81.8) \quad 20(18.2)$

Has already smoked

$43(84.3) \quad 8(15.7)$

$0.008 \quad 0.930$

Currently smokes

$10(76.9) \quad 3(23.1)$

Race

Caucasian

114 (83.2) 23 (16.8)

Black

Asian

Occupational Situation

Active

Non-active

$23(74.2) \quad 8(25.8) \quad 0.018 \quad 0.894$

$6(100.0) \quad 09(0.0)$

$51(76.1) \quad 16(23.9)$

$92(86.0) \quad 15(14.0)$

$2.737 \quad 0.098$

\section{Being retired}

Yes

No

$33(71.7) \quad 13(28.3)$

$110(85.9) \quad 18(14.1)$

$4.6590 .031^{*}$

\section{Being a current student}

Yes

$4(50.0) \quad 4(50.0)$

$139(83.7) \quad 27(16.3)$

$5.9320 .035^{\star}$

Note: *Significant association $-p<0.05$ : Qui-squared Test. 
When analyzing the association of body image dissatisfaction with the health and physical activity variables (Table 4), a significant association was found with health self-perception $(p=0.016)$, body self-perception $(\mathrm{p}=0.001)$, and practice time $(\mathrm{p}=0.027)$. It is noteworthy that there is a higher proportion of individuals who have no body dissatisfaction with good health perception (89.3\%), who perceive themselves as having a normal body (91.9\%) and who have been practicing weight training for more than 6 months.

Table 4 - Association of body image dissatisfaction with the variables related to health and physical activity of the elderly who practice weight training in Maringá - PR

\begin{tabular}{|c|c|c|c|c|}
\hline \multirow{3}{*}{ VARIABLES } & \multicolumn{2}{|c|}{$\begin{array}{l}\text { Body image } \\
\text { dissatisfaction }\end{array}$} & \multirow{3}{*}{$X^{2}$} & \multirow{3}{*}{$\mathbf{P}$} \\
\hline & $\begin{array}{l}\text { Absence } \\
(n=143)\end{array}$ & $\begin{array}{l}\text { Presence } \\
(n=31)\end{array}$ & & \\
\hline & $f(\%)$ & $f(\%)$ & & \\
\hline \multicolumn{5}{|c|}{ Health self-perception } \\
\hline Bad/Regular & 52 (85.2) & $9(14.8)$ & \multirow{3}{*}{5.857} & \multirow{3}{*}{$0.016^{\star}$} \\
\hline Good & 67 (89.3) & $8(10.7)$ & & \\
\hline Very good/Excellent & 24 (63.2) & $14(36.8)$ & & \\
\hline \multicolumn{5}{|l|}{ Body self-perception } \\
\hline Slim & 8 (72.7) & $3(27.3)$ & \multirow{3}{*}{14.222} & \multirow{3}{*}{$0.001^{\star}$} \\
\hline Normal & $113(91.9)$ & $10(8.1)$ & & \\
\hline Fat & $22(55.0)$ & $18(45.0)$ & & \\
\hline \multicolumn{5}{|l|}{ Weight training time } \\
\hline Less than 6 months & $38(70.4)$ & $16(29.6)$ & \multirow{3}{*}{4.908} & \multirow{3}{*}{$0.027^{\star}$} \\
\hline 6 months to 1 year & 53 (88.3) & 7 (11.7) & & \\
\hline More than 2 years & $52(86.7)$ & $8(13.3)$ & & \\
\hline \multicolumn{5}{|l|}{ Weekly frequency } \\
\hline 1 to 2 times & $24(80.0)$ & $6(20.0)$ & \multirow{3}{*}{0.023} & \multirow{3}{*}{0.878} \\
\hline 3 to 4 times & 93 (83.8) & 18 (16.2) & & \\
\hline 5 times or more & $26(78.8)$ & $7(21.2)$ & & \\
\hline \multicolumn{5}{|l|}{ Reason for practicing } \\
\hline $\begin{array}{l}\text { Medical } \\
\text { recommendation }\end{array}$ & $100(80.6)$ & $24(19.4)$ & \multirow{3}{*}{0.031} & \multirow{3}{*}{0.860} \\
\hline Leisure & 37 (90.2) & $4(9.8)$ & & \\
\hline Aesthetics & $6(66.7)$ & 3 (33.3) & & \\
\hline \multicolumn{5}{|l|}{$\begin{array}{l}\text { Being practicing } \\
\text { another exercise }\end{array}$} \\
\hline Yes & $62(86.1)$ & $10(13.9)$ & \multirow{2}{*}{1.294} & \multirow{2}{*}{0.255} \\
\hline No & $81(79.4)$ & $21(20.6)$ & & \\
\hline
\end{tabular}

Note: *Significant association $-\mathrm{p}<0.05$ : Chi-squared Test.

For modeling the regression analysis, only the variables that had a significance level equal to or less than 0.20 for association were considered. Table 5 shows the sociodemographic factors associated with the presence of dissatisfaction with the body image of the elderly. In the gross analysis, there was a significant association $(p<0.05)$ of the presence of dissatisfaction with body image, sex, retirement, current study, body self-perception and practice time.

Table 5 - Factors associated to the presence of body image dissatisfaction of the elderly who practice weight training in Maringá - PR

\begin{tabular}{|c|c|c|}
\hline Variables & OR gross & OR adjusted (C.I. 95\%) \\
\hline Age & $1,032(0,958-1,112)$ & $1,110(1,003-1,251)^{*}$ \\
\hline \multicolumn{3}{|l|}{ Sex } \\
\hline Male & 1.00 & 1.00 \\
\hline Female & $2,201(0,922-5,252)^{*}$ & $3,120(1,019-9,554)^{*}$ \\
\hline \multicolumn{3}{|l|}{ Marital status } \\
\hline With a partner & 1.00 & 1.00 \\
\hline Without a partner & $1,680(0,769-3,670)$ & $2,229(0,817-6,081)$ \\
\hline \multicolumn{3}{|l|}{$\begin{array}{l}\text { Occupational } \\
\text { situation }\end{array}$} \\
\hline Active & 1.00 & 1.00 \\
\hline Non-active & $0,520(0,237-1,137)$ & $0,540(0,162-1,804)$ \\
\hline \multicolumn{3}{|l|}{ Being retired } \\
\hline Yes & 1.00 & 1.00 \\
\hline No & $0,415(0,184-0,936)^{*}$ & $0,390(0,112-1,362)$ \\
\hline \multicolumn{3}{|l|}{$\begin{array}{l}\text { Being a current } \\
\text { student }\end{array}$} \\
\hline Yes & 1.00 & 1.00 \\
\hline No & $0,194(0,046-0,825)^{*}$ & $0,370(0,049-2,825)$ \\
\hline \multicolumn{3}{|l|}{$\begin{array}{l}\text { Health } \\
\text { self-perception }\end{array}$} \\
\hline Bad/Regular & 1.00 & 1.00 \\
\hline Good & $0,690(0,249-1,911]$ & $0,749(0,219-2,567]$ \\
\hline Very good/Excellent & $3,370(1,281-8,865]$ & $1,810(0,493-6,637]$ \\
\hline \multicolumn{3}{|l|}{$\begin{array}{l}\text { Body self- } \\
\text { perception }\end{array}$} \\
\hline Slim & 1.00 & 1.00 \\
\hline Normal & $0,236(0,054-1,033)^{*}$ & $0,225(0,041-1,223)$ \\
\hline Fat & $2,182(0,504-9,450)$ & $1,682(0,316-8,961)$ \\
\hline \multicolumn{3}{|l|}{ Practice time } \\
\hline Less than 6 months & 1.00 & 1.00 \\
\hline 6 months to 1 year & $0,314(0,118-0,837)^{*}$ & $0,413(0,127-1,339)$ \\
\hline More than 2 years & $0,365(0,142-0,941)^{*}$ & $0,465(0,140-1,545)$ \\
\hline
\end{tabular}


When the analysis was adjusted for all the variables, a significant association between the presence of body image dissatisfaction with age and sex $(\mathrm{p}<0.05)$ was seen. It is highlighted that older people and women showed 1,110 (95\% CI = 1,003 to, 251$)$ and $3,120(95 \% \mathrm{CI}=1,019-9,554)$ times more likely to be dissatisfied with body image when compared to younger subjects and men.

\section{Discussion}

The present study aimed at identifying the factors associated with the dissatisfaction with the body image of the elderly who practice weight training, a subject that, although strongly discussed in what refers to how much such dissatisfaction is seen in different contexts [11], it still lacks evidence in the literature regarding the profile of the elderly practitioners who practice weight training. In this sense, the results showed that there is a higher proportion of elderly with absence of body dissatisfaction, most of them are not retired neither been currently studying, and independent the time they practice weight training, the simple act of practice contribute to better perception of body image. Yet, it was found that be women and the older you get, can be an indicative to contribute to the body image dissatisfaction.

With aging, the physical changes that occur in the body are rejected by the elderly due to the image they have of themselves, which can make them develop a feeling of low self-esteem and self-devaluation [12]. For this, practice exercise is important for this population, because for elderly, stay with high selfesteem, can contribute for better self-perception, and purpose of life $[8,13]$.

The majority of weight training practitioners of this study were female. Cardoso et al. [14] also found that older women are more physically active and practice physical activity. The study by Krug et al. [15] also showed that most of the elderly who practice different modalities of physical activity were female. This can be an indicative that it is necessary motivate male elderly to practice more exercise and/ or be more careful with their health.

Another important result was that even in elderly people, be women is a factor that may favor greater body image dissatisfaction. This is found in Weinberger et al. [11] meta-analysis and in Almeida and Baptista [3], who verified that BI dissatisfaction is more evident in women. Comparing with this, the present investigation can contribute for interventions with elderly women, comprehending that even older women can be perfectionist with their body and collaborate with this self-perception.

The studies by Mazo et al. [16] and Meurer et al. [17], carried out with elderly women who regularly participate in regular physical exercise programs. These studies showed a high self-esteem and self-image in the active elderly, and verified that the participation in regular physical activity programs significantly contributes to the improvement of self-esteem and self-image of the elderly, who consequently have a better body satisfaction. Studies with old women report that a reduced number of diseases and the practice of physical activities have a positive effect on satisfaction with self-esteem and body image [18].

Coradini et al. [19] analyzed the body image satisfaction of active elderly women, and then related the physical exercise with body image, thus finding that most of the elderly women were dissatisfied with their body image, but they recognized the benefits provided by physical exercise. Pereira et al. [20] related the anthropometric indicators with the body image perception of elderly women, pointing out that the majority of them were dissatisfied for being overweight. Such results were also found by Chaim, Izzo \& Sera [12], and Londoño and Velasco [21] who showed that the body image dissatisfaction may negatively influence the quality of life.

However, Conterato and Daronco [22] have identified positive changes in the body image perception of elderly women after starting weight training, which reinforces the benefits of the modality for a better self-image. This can be an indicative of the importance of physical exercise during aging, in be a factor for greater self-evaluation and wellbeing. For this, it is important to know why and which kind of exercise elderly looking for.

The study by Zawadski and Vagetti [23], which aimed to know the main reasons that lead the elderly to practice weight training, showed health maintenance and the prevention of diseases as the first reasons. Yet, it is the medical indication, making friends, the improvement of life quality, and increased self-esteem. The present study, the elderly who practice weight training and had no body dissatisfaction go to fitness centers due to medical recommendation and leisure. These indicate that, 
even though the elderly seek the physical exercise by medical indication, for this population, it is extremely important the social contact that the activity provides

The present study shows that the majority (16.7\%) of the elderly dissatisfied with the body image earn more than two minimum wages. A study carried out with elderly women living in low-income communities in the northeastern region of Brazil showed that body dissatisfaction is the main factor associated with insufficient physical activity, even when controlled by sociodemographic factors and other characteristics related to health status [24].

The study by Coelho and Fagundes [25] reports that the higher the purchasing power, the better the relationship with body image, which reflects the variation in body image satisfaction among different social classes that influence the perception of body image. However, the beauty standard imposed by society affects individuals regardless of the social class $[2,26]$.

In the present study $69 \%$ of the elderly have been practicing weight training for 6 months to more than two years. The regular practice of physical activities, besides preventing addictions, is a stimulus to well-being, contributing to an improvement in independence and health self-perception, which reflects in a better self-esteem and life satisfaction $[8,27]$, consequently, a better satisfaction with body image [28].

The improvement of mental and physical health, social life, socialization and friendship are the main reasons that make the elderly begin and remain in physical activity programs $(16,20)$. The participation of the elderly in physical exercise programs, such as weight training, may be a practice that contributes more than physical fitness [29], but can support the quality of life, self-esteem and body satisfaction of the elderly, although there are other aspects that contribute to increase these variables $[27,30]$.

As limitations of this study, the absence of a group of elderly people who do not practice physical exercise is highlighted, as well as elderly people who practice other types of exercise, in order to compare the data. The way of drawing the places of research may also be indicated as a limitation. A research on this same subject with older adults ( 80 years old and more) should be carried out, as well as a follow-up of this population in longitudinal studies in order to understand the behavior of body dissatisfaction with the aging process.

\section{Conclusion}

Based on the results obtained, it can be concluded that the sociodemographic factors can be considered as intervenient ones for body dissatisfaction of the elderly who practice weight training. It is emphasized that, as aging comes, the elderly become increasingly dissatisfied with their own body, and this situation is more evident in women. As practical implications of these findings, it can be pointed out the need of family members and health professionals to be aware of such indicatives in the elderly. In addition, the relevance of regular practice of exercises to reduce this body dissatisfaction is highlighted.

\section{Acknowledgements}

The authors would like to thank the Cesumar Institute for Science, Technology and Innovation (ICETI) and the Coordination for the Upgrading of Personnel in Higher Institutions of Education (CAPES) for scholarships and funding.

\section{References}

1. Laus MF, Kakeshita IS, Costa TMB, Ferreira MEC, Fortes LS, Almeida SS. Body image in Brazil: recent advances in the state of knowledge and methodological issues. Rev Saude Publica. 2014;48(2):331-46.

2. Grogan, S. Body image: Understanding body dissatisfaction in men, women and children. Abingdon-on-Thames, UK: Routledge; 2016.

3. Almeida LLB, Baptista TJR. Análise da imagem corporal de praticantes de atividades físicas em um centro de práticas corporais. Pensar Prat. 2016;19(3):601-11.

4. Fortes LS, Meireles JFF, Neves CM, Almeida SS, Ferreira MEC. Autoestima, insatisfação corporal e internalização do ideal de magreza influenciam os comportamentos de risco para transtornos alimentares? Rev Nutr. 2015;28(3):253-64.

5. Silva AJB, Bruneto BC, Reichert FF. Imagem corporal de praticantes de treinamento com pesos em academias de Londrina, PR. Rev Bras Ativ Fis Saude. 2010;15(3):170-5. 
6. Fonseca CC, Chaves ECL, Pereira SS, Barp M, Moreira AM, Nogueira DA. Autoestima e satisfação corporal em idosas praticantes e não praticantes de atividades corporais. Rev Educ Fis. 2014;25(3):429-39.

7. Matsuo RF, Velardi M, Brandão MRF, Miranda MLJ. Imagem corporal de idosas e atividade física. Rev Mackenzie Educ Fis Esporte. 2007;6(1):37-43.

8. Viana HB, Santos MR. Análise de percepção da imagem corporal e satisfação com a vida em idosos praticantes de hidroginástica. Rev Kairós. 2015;18(2):299-309.

9. Matos CLA. A reinvenção do corpo da mulher idosa: imagens corporais na cultura contemporânea [master's thesis]. Salvador: Universidade Federal da Bahia; 2015.

10. Di Pietro M, Silveira DX. Internal validity, dimensionality and performance of the Body Shape Questionnaire in a group of Brazilian college students. Rev Bras Psiquiatr. 2009;31(1):21-4.

11. Weinberger NA, Kersting A, Riedel-Heller SG, LuckSikorski C. Body Dissatisfaction in Individuals with Obesity Compared to Normal-Weight Individuals: A Systematic Review and Meta-Analysis. Obes Facts. 2016;9(6):424-41.

12. Chaim J, Izzo H, Serra CTN. Cuidar em saúde: satisfação com imagem corporal e autoestima de idosos. Mundo Saúde. 2009;33(2):175-81.

13. Boyle PA, Buchman AS, Bennett DA. Purpose in life is associated with a reduced risk of incident disability among community-dwelling older persons. Am J Geriatr Psychiatry. 2010;18(12):1093-102.

14. Cardoso AS, Levandoski G, Mazo GZ, Prado APM, Cardoso LS. Comparação do nível de atividade física em relação ao gênero de idosos participantes de grupos de convivência. Rev Bras Ci Env Hum. 2008;5(1):9-18.

15. Krug RR, Conceição JCR, Garcia GD, Streit IA, Mazo GZ. Idosos praticantes de atividades físicas: relação entre gênero e idade. Biomotriz. 2011;5(1):1-16.

16. Mazo GZ, Cardoso FL, Aguiar DLD. Programa de hidroginástica para idosos: motivação, auto-estima e auto-imagem. Rev Bras Cineantropom Desempenho Hum. 2006;8(2):67-72.
17. Meurer ST, Benedetti TRB, Mazo GZ. Aspectos da autoimagem e autoestima de idosos ativos. Motriz Rev Educ Fís. 2009;15(4):788-96.

18. Vitoreli E, Pessini S, Silva MJP. A auto-estima de idosos e as doenças crônico-degenerativas. Rev Bras Ci Env Hum. 2006;2(1):102-14.

19. Coradini JG, Silva JR, Comparin KA, Loth EA, Kunz RI. Satisfação da imagem corporal e visão de idosas ativas sob a influência do exercício físico na sua autoimagem. Rev Kairós. 2012;15(5):67-80.

20. Pereira EF, Teixeira CS, Borgatto AF, Daronco LSE. Relação entre diferentes indicadores antropométricos e a percepção da imagem corporal em idosas ativas. Rev Psiq Clín. 2009;36(2):54-9.

21. Londoño CP, Velasco MS. Estilo de afrontamiento, optimismo disposicional, depresión, imagen corporal, IMC, y riesgo de TCA como predictores de calidad de vida relacionada con la salud. Psychol Av Discip. 2015;9(2):35-47.

22. Conterato MV, Daronco LSE. Imagem corporal de idosos praticantes de musculação. 11o Congreso Argentino de Educación Física y Ciencias; 2015 Sep 23 - Oct 10; Ensenada, Argentina. Buenos Aires: Memoria Académica, Universidad Nacional de La Plata; 2015.

23. Zawadski ABR, Vagetti GC. Motivos que levam idosas a frequentarem as salas de musculação. Rev Mov Percep. 2007;7(10):45-60.

24. Tribess S, Virtuoso-Junior JS, Petroski EL. Fatores associados à inatividade física em mulheres idosas em comunidades de baixa renda. Rev Salud Pública. 2009;11(1):39-49.

25. Coelho EJN, Fagundes TF. Imagem corporal de mulheres de diferentes classes econômicas. Motriz Rev Educ Fís. 2007;13(Supl 2):S37-43.

26. McLaren L, Groot J, Adair CE, Russell-Mayhen S. Socio-economic position, socio inequality and weightrelated issues. In: McVey GL, Levine MP, Piran N, Ferguson HB. editors. Preventing Eating-Related and Weight-Related Disorders: Collaborative Research, Advocacy, and Policy Change. Waterloo, ON: Wilfrid Laurier University Press; 2012. p. 249-68. 
27. Antunes G, Mazo GZ, Balbé GP. Relação da autoestima entre a percepção de saúde e aspectos sociodemográficos de idosos praticantes de exercício físico. Rev Educ Fís. 2011;22(4):583-9.

28. Gledhill LJ, Cornelissen KK, Cornelissen PL, PentonVoak IS, Munafò MR, Tovée MJ. An interactive training programme to treat body image disturbance. Br J Health Psychol. 2017;22(1):60-76.

29. Dias RMR, Gurjão ALD, Marucci MDFN. Benefícios do treinamento com pesos para aptidão física de idosos. Acta Fisiatr. 2016;13(2):90-5.
30. Park SH, Han KS, Kang CB. Effects of exercise programs on depressive symptoms, quality of life, and self-esteem in older people: a systematic review of randomized controlled trials. Appl Nurs Res. 2014;27(4):219-26.

Received in 06/19/2017

Recebido em 19/06/2017

Approved in 10/07/2017

Aprovado em 07/10/2017 